\title{
Effects of Glucose on the Production by Escherichia coli of Hydrogen Sulphide from Cysteine
}

\author{
By DOROTHY C. ANDERSON AND K. R. JOHANSSON \\ Department of Microbiology, University of Minnesota, Minneapolis 14, \\ Minnesota, U.S.A.
}

(Received 29 June 1962)

\begin{abstract}
SUMMARY
Glucose and certain other sugars accelerated hydrogen sulphide production from L-cysteine by washed cells of Escherichia coli (strain Crookes) which had been grown in the presence of L-cysteine. On the other hand, glucose or some other sugars in protein hydrolysate media containing L-cysteine suppressed the synthesis of an enzyme(s) which mediates the formation of hydrogen sulphide from L-cysteine. Glucose accelerated sulphide formation from L-cysteine by sonicated preinduced cells, although activity was unstable to such treatment. Both effects of glucose were influenced by the amino acid content of the medium. Sulphide production probably resulted through the action of cysteine desulphydrase; certain evidence suggested that a transaminase linked to $\beta$-mercaptopyruvate desulphurase also may have functioned. Apparently glucose repressed the induction of one or more enzymes concerned with cysteine degradation.
\end{abstract}

\section{INTRODUCTION}

The ability of glucose and other fermentable carbohydrates to suppress the formation of a variety of inducible enzymes in bacteria is well established, although the mechanism has not been elucidated fully (Cohn \& Horibata, 1959; Magasanik, 1957; Magasanik, Magasanik \& Neidhardt, 1959; Magasanik, 1962; Pardee, 1961; Pardee \& Prestidge, 1961). During the course of an investigation of the production of hydrogen sulphide from L-cysteine it was noted that the presence of glucose in tryptone broth cultures of Escherichia coli (strain Crookes) presumably inhibited the induction of cysteine desulphydrase, an inducible enzyme (Fromageot, 1951), whereas glucose stimulated hydrogen sulphide production from cysteine by preinduced organisms (cf. Desnuelle \& Fromageot 1939). This report will describe these effects of glucose and certain other fermentable carbohydrates and will present some evidence for nutritional regulation of the production of the enzyme(s) which liberate hydrogen sulphide from L-cysteine.

\section{METHODS}

Micro-organism. Escherichia coli, strain Crookes (ATCC 8739).

Culture media. Two basal media were used: (i) a mineral salts defined medium (Davis \& Mingioli, 1950) to which glucose (generally $0.5 \%, \mathrm{w} / \mathrm{v}$ ) and/or monosodium glutamate $(0.5$ or $\mathbf{1 . 0} \%, \mathrm{w} / \mathrm{v})$ were added; and (ii) a crude complex medium containing $(\%, \mathrm{w} / \mathrm{v})$ Bacto-tryptone (1.0) and $\mathrm{K}_{2} \mathrm{HPO}_{4}(0 \cdot 12)$. The media were 
dispensed in $250 \mathrm{ml}$. quantities in $500 \mathrm{ml}$. Erlenmeyer flasks which were stoppered with gauze-wrapped cotton and autoclaved for $20 \mathrm{~min}$. at $121^{\circ}$. Glucose was autoclaved separately as an aqueous $10 \%(\mathrm{w} / \mathrm{v})$ solution and, when needed, added aseptically to the sterilized medium. L-cysteine. HCl was sterilized by filtration of a freshly prepared aqueous solution through a UF sintered glass filter and added aseptically $(0.05$ or $0.1 \%, \mathrm{w} / \mathrm{v})$ to the sterile medium prior to inoculation. Other modifications of the media will be described in Results. The medium was adjusted to the desired $\mathrm{pH}$ value with sterile $\mathrm{NaOH}$ or $\mathrm{HCl}$, just before inoculation.

Production and preparation of organisms. Stock cultures of Escherichia coli were maintained by monthly transfer on nutrient agar slopes. The inoculum for $250 \mathrm{ml}$. of medium was $0.75 \mathrm{ml}$. of a $24 \mathrm{hr}$. culture grown at $37^{\circ}$ in a medium of the same composition as that in the flask. The inoculated flasks of media were incubated at $37^{\circ}$ under static conditions, generally for 12-16 hr. The organisms were harvested by centrifugation for $30 \mathrm{~min}$. at $1800 \mathrm{~g}$ and resuspended in $5 \mathrm{ml}$. de-ionized water. After a second washing in de-ionized water the organisms were stored in the packed state at $4^{\circ}$ for no more than $4 \mathrm{hr}$. prior to assay for cysteine desulphydrase activity. Further washing or prolonged storage, especially in the unpacked state, markedly decreased any desulphydrase activity.

Assay for hydrogen sulphide production. One volume of a freshly prepared concentrated buffered substrate solution (16 or $32 \mathrm{mM}$ L-cysteine. HCl, $0 \cdot 1$ or $0.2 \mathrm{M}$ $\mathrm{KH}_{2} \mathrm{PO}_{4}, 0.05 \mathrm{M}-\mathrm{MgSO}_{4}$; adjusted to $\mathrm{pH} 6.4$ with $0.1 \mathrm{~N}-\mathrm{NaOH}$ ) was mixed with four volumes of washed organisms resuspended from the packed state in de-ionized water to a density of $0.75-1.5 \mathrm{mg}$. dry weight. Replicate $5 \mathrm{ml}$. quantities of the substrate-organism suspension were placed in Pyrex tubes $(12 \times 100 \mathrm{~mm}$.) with rubber stoppers to minimize entrance of air and incubated at $37^{\circ}$ in a water bath. At intervals tubes were removed, $0 \cdot 25 \mathrm{ml}$. of a $40 \%(\mathrm{w} / \mathrm{v})$ solution of $\mathrm{NaOH}$ was added to terminate the reaction and the stoppers were replaced. The tubes were gently agitated for $20 \mathrm{~min}$. at room temperature, and the cell-free supernatant fluid recovered after centrifugation for $10 \mathrm{~min}$. at $2800 \mathrm{~g}$. The supernatant fluid was assayed for hydrogen sulphide within $2 \mathrm{hr}$. by a modification of the method of Delwiche (1951) : 1-4 ml. of the supernatant fluid was mixed with $2 \mathrm{ml}$. of $2 \mathrm{~N}-\mathrm{NaOH}, 4 \mathrm{ml}$. lead acetate reagent ( $\mathrm{Pb}$ acetate, 1.0 g.; glacial acetic acid, $2.5 \mathrm{ml}$; gum arabic, $2.5 \mathrm{~g}$.; distilled water to 1 l.) was added and the resulting brownish yellow colour was measured promptly in a Klett-Summerson photoelectric colorimeter (filter 54) previously adjusted to $100 \%$ transmission with a reagent blank. The readings were compared with those of an alkaline sodium sulphide solution standardized by iodometric titration (Bethge, 1953). Over a limited range in concentration of sulphide, a plot of colorimeter readings against $\mu \mathrm{M}$-sulphide yielded a straight line. The assay was simple and reproducible (replicates agreed within limits of $\pm 1 \%$ two-thirds of the time), being sensitive to $0 \cdot 1 \mu \mathrm{g}$. $\mathrm{H}_{2} \mathrm{~S} / \mathrm{ml}$. substrate solution.

Assay for ammonia production. Portions of the same washed suspensions as employed for the assay of hydrogen sulphide were tested on occasion for their ability to produce ammonia from L-cysteine; in such experiments the reaction was terminated with $\mathbf{0 . 2 5} \mathrm{ml}$. of $\mathbf{5 0} \%$ (w/v) trichloroacetic acid. Ammonia was released by $\mathrm{K}_{2} \mathrm{CO}_{3}$ solution, absorbed in $1 \%(\mathrm{w} / \mathrm{v})$ boric acid contained in Pyrex microdiffusion dishes $(64 \mathrm{~mm}$. diameter, $15 \mathrm{~mm}$. deep, $37 \mathrm{~mm}$. diameter centre well), 
and titrated with $0.002 \mathrm{~N}-\mathrm{HCl}$ (Conway, 1950). The distilled water and reagents were checked for any traces of ammonia and a suitable correction applied when necessary.

Terminology. The term cysteine desulphydrase will connote the biological formation of hydrogen sulphide from L-cysteine, although other pathways of sulphide production from cysteine may have functioned under certain conditions (see Discussion). Cysteine desulphydrase activity was expressed as $\boldsymbol{Q}_{\mathrm{H}_{2} \mathrm{~S}}\left(\mu \mathrm{g} \cdot \mathrm{H}_{2} \mathrm{~S}\right.$ produced $/ \mathrm{mg}$. dry cells/hr.) estimated from the amount of product formed over a period of time during which not more than $20 \%$ of the cysteine sulphur appeared as sulphide.

\section{RESULTS}

Optimal cultural conditions for cysteine desulphydrase activity. Although cystine and cysteine are present in Bacto-tryptone, supplementation of the tryptone broth with L-cysteine. $\mathrm{HCl}$ encouraged desulphydrase production (cf. Kallio \& Porter, 1950). Preliminary experiments showed that organisms of highest specific activity were obtained from tryptone broth $(a)$ devoid of glucose, $(b)$ supplemented with $0.1 \%(\mathrm{w} / \mathrm{v})$ L-cysteine. $\mathrm{HCl},(c)$ adjusted to $\mathrm{pH} 5.5$ and $(d)$ incubated at $37^{\circ}$ for 10-16 hr. In the defined medium, cysteine-or possibly sulphide arising from degradation of this amino acid-was inhibitory to growth when serving as the sole energy source, although the meagre number of organisms which appeared after several days of incubation at $37^{\circ}$ had good desulphydrase activity. Supplementation of the defined medium containing L-cysteine $(0.05 \%, \mathrm{w} / \mathrm{v})$ with glucose $(0 \cdot 1 \%, \mathrm{w} / \mathrm{v})$ partially overcame the toxicity of cysteine. Monosodium glutamate or aspartic acid $(0 \cdot 1 \%, w / v)$ supported excellent growth in the cysteine-supplemented defined medium, but did not produce organisms with good cysteine desulphydrase activity unless the medium was fortified also with glucose. The initial $\mathrm{pH}$ of the defined medium was generally adjusted to $6 \cdot 0-6 \cdot 4$, being not as critical toward formation of cysteine desulphydrase as was noted for tryptone broth.

Effect of test conditions. In addition to the nature of the culture medium, the composition of the substrate solution in which washed cells were suspended for determination of desulphydrase activity was important. Since the enzymic desulphydration of cysteine is an anaerobic process, the presence of oxygen or oxidative processes may lead to non-enzymic loss of sulphide and cysteine, or influence the pathway of dissimilation (Kallio, 1951; Tamiya, 1954). Incubation in the small rubberstoppered tubes, almost completely filled with substrate +organism suspension, apparently maintained conditions sufficiently anaerobic for good activity. Flushing with nitrogen before incubation resulted in no improvement of activity or stability of the desulphydrase system. Additions to the buffered substrate of mercaptoethanol or ascorbic acid had no detectable effect, while sodium thioglycolate increased, after a delay, the yield of sulphide, possibly by non-enzymic degradation of thioglycolate (Olitzki, 1954). On the other hand, reduced gluthathione lowered the output of sulphide. Although the cysteine codesulphydrase is a derivative of vitamin $\mathbf{B}_{6}$, additions of pyridoxine, pyridoxal or pyridoxal phosphate to the substrate solution had no effect on the desulphydrase activity of induced cells. (Likewise, additions of $\mathbf{B}_{6}$ to the culture medium had no effect on induction.) In agreement with the reports of a number of investigators, arsenate, cyanide, monoiodoacetate and azide, at 
concentrations of $10^{-3} \mathrm{M}$ in the substrate solution, were found to be inhibitory to cysteine desulphydrase. Fluoride also was highly inhibitory, although it has been reported to have no influence on this enzyme in cell-free liver preparations (Fromageot, Wookey \& Chaix, 1940).

Table 1. Effects of glucose in the medium and in the cysteine substrate solution on L-cysteine desulphydrase activity of Escherichia coli strain Crookes

Organisms were grown in the media indicated and tested for desulphydrase activity as washed suspensions in the presence or absence of glucose (see Methods). Results from two separate experiments, one of which tested a graded series of glucose concentrations.

\begin{tabular}{|c|c|c|c|c|c|c|c|c|c|c|}
\hline \multirow{2}{*}{ Growth medium } & \multicolumn{2}{|c|}{$\mathbf{p H *}$} & \multirow[t]{2}{*}{0} & & \multirow{2}{*}{\multicolumn{3}{|c|}{ 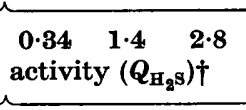 }} & \multirow[t]{2}{*}{$\mathbf{5 \cdot 5}$} \\
\hline & Initial & Final & & & & & & & & \\
\hline Tryptone + cysteine & $5 \cdot 7$ & $5 \cdot 8$ & $9 \cdot 0$ & - & - & - & - & - & $31 \cdot 0$ & - \\
\hline$(\mathbf{3 . 2} \mathrm{mm})$ & $5 \cdot 5$ & $5 \cdot 7$ & $9 \cdot 0$ & $13 \cdot 7$ & $16 \cdot 7$ & $18 \cdot 0$ & - & $25 \cdot 6$ & - & $51 \cdot 0$ \\
\hline $\begin{array}{c}\text { Same + glucose } \\
(0.1 \%, w / v)\end{array}$ & $5 \cdot 7$ & $5 \cdot 3$ & $0 \cdot 6$ & 一 & - & - & - & - & $1 \cdot 4$ & 一 \\
\hline $\begin{array}{l}\text { Defined + cysteine } \\
(\mathbf{3 \cdot 2} \mathrm{mm})+\text { glutamate } \\
(\mathbf{1} \%, \mathbf{w} / \mathbf{v})\end{array}$ & $6 \cdot 4$ & $6 \cdot 4$ & $1 \cdot 6$ & - & 一 & 一 & - & 一 & $97 \cdot 0$ & 一 \\
\hline Same + glucose & $6 \cdot 4$ & $5 \cdot 0$ & $\mathbf{3 0 \cdot 0}$ & - & - & - & - & - & $60 \cdot 0$ & - \\
\hline$(1.0 \%$ and $0.5 \%, w / v)$ & $5 \cdot 7$ & $4 \cdot 7$ & $\mathbf{3 0} \cdot \mathbf{5}$ & 一 & 一 & $39 \cdot 5$ & $45 \cdot 0$ & $51 \cdot 0$ & 一 & $\mathbf{5 4} \cdot \mathbf{0}$ \\
\hline
\end{tabular}

Table 2. Effects of various sugars on activity of L-cysteine desulphydrase

Organisms were grown in the defined glutamate-cysteine medium and tested for activity as washed suspensions in the presence of the indicated sugars $(0.5$ or $1.0 \mathrm{mg} . / \mathrm{ml}$. buffered L-cysteine solution; see Methods). The sugars were reagent grade and were not checked for purity.

\begin{tabular}{|c|c|c|}
\hline \multirow{2}{*}{$\begin{array}{l}\text { Nature of sugar } \\
\text { present during } \\
\text { test }\end{array}$} & \multicolumn{2}{|c|}{ Glucose in medium $(\%, w / v)$} \\
\hline & $0 *$ & $\boldsymbol{Q}_{\mathbf{H}_{2}} \mathbf{s}{ }^{\dagger}$ \\
\hline Control & $16 \cdot 5$ & $21 \cdot 4$ \\
\hline Glucose & $106 \cdot 0$ & $148 \cdot 0$ \\
\hline Xylose & $18 \cdot 6$ & $\mathbf{2 3} \cdot \mathbf{4}$ \\
\hline Fructose & $82 \cdot 4$ & $118 \cdot 0$ \\
\hline Galactose & $30 \cdot 0$ & $24 \cdot 6$ \\
\hline Sucrose & $109 \cdot 0$ & $57 \cdot 0$ \\
\hline
\end{tabular}

Influence of glucose and other sugars on the formation and activation of cysteine desulphydrase. Regardless of its presence in the growth medium, glucose $\left(5 \cdot 4 \times 10^{-6} \mathrm{M}\right.$ or more) increased the desulphydrase activity of washed Escherichia coli recovered from media supplemented with L-cysteine (Table 1). The stimulatory effect of glucose of desulphydrase activity was of the same order as that of sucrose or fructose while xylose and galactose were slightly stimulatory (Table 2). The presence of glucose 
in the medium, however, either enhanced (defined medium) or inhibited (tryptone broth) the formation of the enzyme (Table 1). The latter effect was detectable at a glucose concentration of $0.01 \%(w / v)$ (Table 3) and was essentially duplicated by five other sugars (Table 4).

Table 3. Sensitivity of formation of cysteine desulphydrase to glucose in tryptone broth

Organisms were grown in tryptone broth (initial pH of $6 \cdot 0$ ) containing various concentrations of glucose and tested as washed suspensions for activity in the buffered L-cysteine solution (with and without $0.5 \mathrm{mg}$. glucose/ $\mathrm{ml}$.; see Methods). Activity expressed as $Q_{\mathrm{H}_{2} \mathrm{~s}}$ ( $\mu \mathrm{g}$. $\mathrm{H}_{2} \mathrm{~S} / \mathrm{hr}$./mg. washed dry organisms).

\begin{tabular}{|c|c|c|c|}
\hline \multirow{2}{*}{$\begin{array}{l}\text { Glucose } \\
\text { concentration } \\
\text { in medium } \\
(\%, w / v)\end{array}$} & \multirow[b]{2}{*}{ Final $\mathrm{pH}$} & \multicolumn{2}{|c|}{$\begin{array}{l}\text { Activity in L-cysteine solution } \\
\text { containing glucose concentration } \\
\text { of }(\mathrm{mg} . / \mathrm{ml} .)\end{array}$} \\
\hline & & 0 & 1 \\
\hline $\mathbf{0}$ & $6 \cdot 0$ & $10 \cdot 0$ & $\mathbf{3 0} \cdot \mathbf{0}$ \\
\hline 0.01 & $6 \cdot 1$ & $9 \cdot 2$ & $21 \cdot 0$ \\
\hline 0.05 & $5 \cdot 8$ & $3 \cdot 0$ & $16 \cdot 5$ \\
\hline $0 \cdot 10$ & $5 \cdot 3$ & $1 \cdot 5$ & $9 \cdot 0$ \\
\hline 0.20 & 4.7 & 0.5 & 4.0 \\
\hline
\end{tabular}

Table 4. Effect of various sugars in tryptone broth upon L-cysteine desulphydrase activity of Escherichia coli

Organisms were grown in L-cysteine-fortified tryptone broth containing one of the indicated sugars and tested as washed suspensions for activity in the buffered L-cysteine solution (see Methods).

\begin{tabular}{|c|c|c|c|c|}
\hline \multirow[b]{2}{*}{ Sugar in medium } & \multirow{2}{*}{$\begin{array}{c}\text { Concn. of sugar } \\
(\%, w / v)\end{array}$} & \multicolumn{2}{|c|}{ pH* } & \multirow[b]{2}{*}{$Q_{\mathrm{H}_{2} \mathrm{~s}} \dagger$} \\
\hline & & Initial & Final & \\
\hline Control & - & $5 \cdot 6$ & $5 \cdot 8$ & $46 \cdot 2$ \\
\hline Fructose & $\begin{array}{l}0.05 \\
0.30\end{array}$ & $\begin{array}{l}5 \cdot 6 \\
5 \cdot 6\end{array}$ & $\begin{array}{l}5 \cdot 4 \\
4 \cdot 7\end{array}$ & $\begin{array}{l}6 \cdot 4 \\
0 \cdot 4\end{array}$ \\
\hline Galactose & $\begin{array}{l}0 \cdot 05 \\
0 \cdot 30\end{array}$ & $\begin{array}{l}5 \cdot 5 \\
5 \cdot 5\end{array}$ & $\begin{array}{l}5 \cdot 4 \\
4 \cdot 9\end{array}$ & $\begin{array}{r}14 \cdot 6 \\
0 \cdot 3\end{array}$ \\
\hline Glucose & $\begin{array}{l}0.05 \\
0.30\end{array}$ & $\begin{array}{l}5 \cdot 6 \\
5 \cdot 6\end{array}$ & $\begin{array}{l}5 \cdot 4 \\
4.7\end{array}$ & $\begin{array}{l}3 \cdot 6 \\
0.5\end{array}$ \\
\hline Lactose & $\begin{array}{l}0 \cdot 05 \\
0 \cdot 30\end{array}$ & $\begin{array}{l}5 \cdot 7 \\
5 \cdot 7\end{array}$ & $\begin{array}{l}5 \cdot 3 \\
4 \cdot 9\end{array}$ & $\begin{array}{r}10 \cdot 6 \\
2 \cdot 6\end{array}$ \\
\hline Sucrose & $\begin{array}{l}0.05 \\
0.30\end{array}$ & $\begin{array}{l}5 \cdot 5 \\
5 \cdot 5\end{array}$ & $\begin{array}{l}5 \cdot 8 \\
5 \cdot 4\end{array}$ & $\begin{array}{r}20 \cdot 4 \\
1 \cdot 6\end{array}$ \\
\hline Xylose & $\mathbf{0} \cdot 30$ & $5 \cdot 5$ & 4.8 & 0.5 \\
\hline & & $\begin{array}{l}\text { able } 1 . \\
\text { able } 1 .\end{array}$ & & \\
\hline
\end{tabular}

The observed stimulatory action of glucose on the cysteine desulphydrase activity of intact pre-induced organisms could be interpreted as a need for an exogenously supplied source of energy for maximal absorption of substrate. Escherichia coli was grown in the defined cysteine + glutamate + glucose medium: the organisms were washed once with distilled water and exposed to vibrations of a Raytheon $9 \mathrm{KC}$ Sonic Oscillator (Model S-102A, 50 W., frequency maximal, plate voltage of 
78) for various measured times while being cooled with ice water. Plate counts in a nutrient agar were made of portions of the suspension removed at each time interval; the remainder of each sample was diluted with the buffered substrate and tested for cysteine desulphydrase activity. Activity declined rapidly in particulate as well as in the supernatant fractions; viability paralleled rather closely loss in enzyme activity as determined in the presence of glucose. In the absence of glucose, enzyme activity was found to decline more rapidly than loss in viability during the first $8 \mathrm{~min}$. of sonication (Table 5). Nevertheless, at every interval of treatment, especially during the first $6 \mathrm{~min}$., glucose enhanced the apparent activity of cysteine desulphydrase. Similar results were obtained with cells grown in tryptone-cysteine broth. These data suggest that glucose activation of cysteine desulphydrase operates within the cytoplasm.

\title{
Table 5. Effects of glucose on desulphydrase activity of sonicated Escherichia coli
}

\begin{abstract}
Organisms were grown in the defined glutamate + glucose + cysteine medium, washed, sonicated and tested for activity in the presence and absence of glucose (see Methods). The initial $\mathrm{pH}$ of the medium was $5 \cdot 8$; final $\mathrm{pH}$ was $5 \cdot 1$. Viable organisms remaining after sonication were enumerated by customary plate count method. Activity expressed as $Q_{\mathrm{H}_{2} \mathrm{~S}}\left(\mu \mathrm{g} . \mathrm{H}_{2} \mathrm{~S} / \mathrm{hr}\right.$./mg. washed dry organisms).
\end{abstract}

$\begin{array}{cc}\begin{array}{c}\text { Period of } \\ \text { exposure } \\ \text { (min.) }\end{array} & \begin{array}{c}\text { Viable organisms } \\ \text { (no./ml.) }\end{array} \\ 0 & 6.9 \times 10^{9} \\ 2 & 4.4 \times 10^{9}(64 \%) \dagger \\ 4 & 2 \cdot 3 \times 10^{9}(33 \%) \\ 6 & 1.9 \times 10^{9}(28 \%) \\ 8 & 7.7 \times 10^{8}(11 \%) \\ 10 & 3.0 \times 10^{8}(4.3 \%) \\ 12 & 1.8 \times 10^{8}(2 \cdot 6 \%) \\ 15 & 6.0 \times 10^{7}(0.9 \%)\end{array}$

Activity in L-cysteine solution containing

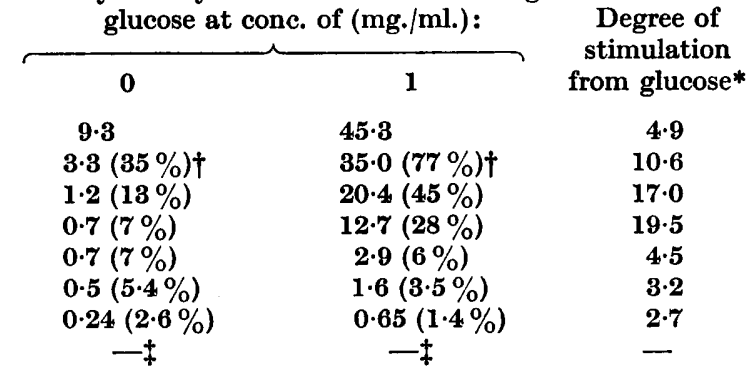

* Ratio of activity in presence of glucose to that in absence of glucose.

$\uparrow$ Figures in parentheses indicate percentile viability or activity remaining after indicated period of treatment.

\$ Negligible activity.

Since the cysteine desulphydrase reaction produces equimolar amounts of sulphide, ammonia and pyruvic acid (Fromageot, 1951; Meister, 1957), simultaneous analysis for more than one of these products might indicate whether cysteine desulphydrase was solely responsible for the production of hydrogen sulphide by L-cysteineinduced suspensions of Escherichia coli. Pre-induced washed organisms were therefore suspended in the buffered cysteine substrate solution at $37^{\circ}$ and desulphydrase activity assayed by measuring both hydrogen sulphide and ammonia evolution. The ratio of $\mathrm{H}_{2} \mathrm{~S}: \mathrm{NH}_{3}$ was consistently very close to $1 \cdot 0$. Glucose $(0 \cdot 5 \mathrm{mg} . / \mathrm{ml}$. buffered cysteine substrate solution) or $\alpha$-ketoglutaric acid $(0.5 \mathrm{mg} . / \mathrm{ml}$.), however, upset this ratio and altered the rates of appearance of the two products: glucose accelerated the rate of production of both products and raised the ratio of $\mathrm{H}_{2} \mathrm{~S}: \mathbf{N H}_{3}$ (on occasion to as high as 1.5 ), while $\alpha$-ketoglutarate slowed down the reaction rates and lowered the initial $(20 \mathrm{~min}$.) ratio. A mixture of glucose and $\alpha$-ketoglutarate moderately accelerated production of sulphide and ammonia and raised the 
$\mathrm{H}_{2} \mathrm{~S}-\mathrm{NH}_{3}$ ratio, especially during the first $20 \mathrm{~min}$. of incubation (Table 6). These deviations might result from interposition of other enzyme(s) leading to release of sulphide and ammonia from transamination or degradation products of L-cysteine. One such mechanism could yield alanine (see Discussion) but alanine was not detected by paper chromatography of vacuum-distilled concentrates from active cell-substrate preparations exposed to glucose. Control strips clearly resolved L-alanine and L-cysteine. No attempts were made to detect glutamic acid in preparations exposed to $\alpha$-ketoglutarate.

\section{Table 6. Stoicheiometry of hydrogen sulphide and ammonia formation from $\mathrm{L}-c y$ steine and the influence of glucose and $\alpha$-ketoglutarate}

Organisms were grown in the defined glutamate + glucose + cysteine medium (initial $\mathrm{pH}$ of 6.5 ; final $\mathrm{pH}$ of $5 \cdot 2$ ) and tested as washed suspensions for desulphydrase activity by quantitating the $\mathrm{NH}_{3}$ and $\mathrm{H}_{2} \mathrm{~S}$ formed after 20 and $60 \mathrm{~min}$. exposure to buffered $\mathrm{L}$-cysteine solution containing $0.5 \mathrm{mg}$. $\alpha$-ketoglutaric acid and/or glucose per $\mathrm{ml}$. (see Methods and Results). Activity expressed as $\mu$ mole $\mathrm{NH}_{3}$ or $\mathrm{H}_{2} \mathrm{~S}$ formed/mg. dry cells over indicated time.

Activity in the presence of:

\begin{tabular}{|c|c|c|c|c|c|c|c|c|c|}
\hline $\begin{array}{c}\text { Incuba } \\
\text { tion } \\
\text { period } \\
\text { (min.) }\end{array}$ & $\begin{array}{l}\text { Product } \\
\text { formed }\end{array}$ & Control & Ratio* & $\begin{array}{l}\alpha \text {-Keto- } \\
\text { glutarate }\end{array}$ & Ratio & Glucose & Ratio & $\begin{array}{c}\alpha \text {-Keto- } \\
\text { glutarate } \\
+ \\
\text { glucose }\end{array}$ & Ratio \\
\hline 20 & $\begin{array}{l}\mathrm{H}_{2} \mathrm{~S} \\
\mathrm{NH}_{3}\end{array}$ & $\left.\begin{array}{l}0 \cdot 74 \\
0 \cdot 74\end{array}\right\}$ & $1 \cdot 00$ & $\left.\begin{array}{l}0 \cdot 41 \\
0.78\end{array}\right\}$ & $\mathbf{0 . 5 3}$ & $\left.\begin{array}{l}2 \cdot 17 \\
1 \cdot 75\end{array}\right\}$ & $1 \cdot 24$ & $\left.\begin{array}{l}1.61 \\
1.09\end{array}\right\}$ & $1 \cdot 48$ \\
\hline 60 & $\begin{array}{l}\mathbf{H}_{2} \mathrm{~S} \\
\mathrm{NH}_{3}\end{array}$ & $\left.\begin{array}{l}1 \cdot 63 \\
1 \cdot 51\end{array}\right\}$ & $1 \cdot 08$ & $\left.\begin{array}{l}0.95 \\
0.87\end{array}\right\}$ & 1.09 & $\left.\begin{array}{l}3 \cdot 02 \\
2 \cdot 30\end{array}\right\}$ & 1.31 & $\left.\begin{array}{l}1.71 \\
1.53\end{array}\right\}$ & $1 \cdot 12$ \\
\hline
\end{tabular}

Efficiency of enzyme action. Tryptone-grown organisms were able to convert from 85 to $95 \%$ of cysteine sulphur to sulphide, regardless of the presence of glucose in the substrate solution, while sulphide produced from cysteine by organisms recovered from the defined glucose + glutamate medium never exceeded, in the absence of glucose, an $80 \%$ conversion. In the presence of glucose, the latter organisms converted less than $65 \%$ of the cysteine sulphur to sulphide. Prolonged incubation of these preparations resulted in the gradual formation of a pronounced yellow colloid material, most intense in the depth of the tube, which disappeared within $\mathbf{3 0} \mathrm{min}$. after unstoppering the tube. No attempt was made to identify this chromogenic material, but it might have been polysulphide formed through degradation of $\beta$ mercaptopyruvic acid (Hylin \& Wood, 1959).

Interaction of glucose and organic nitrogen in the medium on induction of cysteine desulphydrase. Because glucose exerted different effects in the two basal media on the hydrogen sulphide-producing competency of Escherichia coli, the influence of various relative amounts of amino nitrogen and glucose as nutrients on the induction of cysteine desulphydrase was examined. One such experiment (Table 7) indicated that glucose as a constituent of the medium enhanced the resultant desulphydrase activity of organisms from the defined cysteine-glutamate medium, but only if the organic nitrogen mixture (Casitone, Difco) was omitted or very limited during growth. Glucose activation of the system lessened as the amount of amino 
nitrogen in the medium was raised. Highest activities were obtained with organisms grown in media containing Casitone, but not more than $0.01 \%(w / v)$ glucose, provided activity was determined in the presence of glucose. The omission of glutamate from the medium had no apparent effect on these findings.

Table 7. Inter-relationship between casein hydrolysate and glucose in medium on cysteine desulphydrase formation by Escherichia coli during growth

The various indicated amounts and combinations of an enzymic casein hydrolysate (Casitone, Difco) and glucose were incorporated in the defined monosodium glutamate $(0.8 \%, \mathrm{w} / \mathrm{v})+\mathrm{L}$-cysteine.HCl $(0.05 \%, \mathrm{w} / \mathrm{v})$ basal medium. Organisms were tested for activity as washed suspensions in the buffered L-cysteine solution (with and without $1.0 \mathrm{mg}$. glucose $/ \mathrm{ml}$; ; see Methods and Results). The initial pH of all media was 5.8. Activity expressed $Q_{\mathrm{H}_{2} \mathrm{~s}}$ ( $\mu \mathrm{g}$. $\mathrm{H}_{2} \mathrm{~S} / \mathrm{hr}$. $/ \mathrm{mg}$. washed dry organisms).

Addition to medium

\begin{tabular}{ccc}
\hline $\begin{array}{c}\text { Casitone } \\
(\%, w / v)\end{array}$ & $\begin{array}{c}\text { Glucose } \\
(\%, w / v)\end{array}$ & $\begin{array}{c}\text { Fina } \\
\text { pH }\end{array}$ \\
0 & 0 & $5 \cdot 9$ \\
& $0 \cdot 01$ & $5 \cdot 8$ \\
$0 \cdot 10$ & $5 \cdot 1$ \\
0.05 & $0 \cdot 20$ & $5 \cdot 2$ \\
& 0 & $5 \cdot 7$ \\
& $0 \cdot 01$ & $5 \cdot 8$ \\
& $0 \cdot 10$ & $5 \cdot 1$ \\
0.50 & $0 \cdot 20$ & $5 \cdot 1$ \\
& 0 & $5 \cdot 9$ \\
& $0 \cdot 01$ & $5 \cdot 8$ \\
& $0 \cdot 10$ & $5 \cdot 3$ \\
& $0 \cdot 20$ & $5 \cdot 0$
\end{tabular}

Activity in L-cysteine solution containing glucose concentration

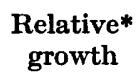

36
216
254
298
76
147
324
320
180
216
404
396
of $(\mathbf{m g} \cdot / \mathrm{ml}$.):

\begin{tabular}{rr}
\hline 0 & 1 \\
\hline $19 \cdot 8$ & $230 \cdot 0$ \\
$54 \cdot 7$ & $196 \cdot 0$ \\
$95 \cdot 0$ & $163 \cdot 0$ \\
$13 \cdot 7$ & $193 \cdot 0$ \\
$30 \cdot 1$ & $418 \cdot 0$ \\
$25 \cdot 4$ & $318 \cdot 0$ \\
$40 \cdot 5$ & $119 \cdot 0$ \\
$4 \cdot 9$ & $98 \cdot 7$ \\
$5 \cdot 6$ & $347 \cdot 0$ \\
$8 \cdot 1$ & $312 \cdot 0$ \\
$4 \cdot 8$ & $43 \cdot 6$ \\
& $27 \cdot 0$
\end{tabular}

* Scale reading of Klett-Summerson photoelectric colorimeter with filter no. 12.

Effects of glucose on the cysteine desulphydrase activity of other strains of Escherichia coli. Three stock (ATCC 9637, 10795, 10586) and three wild strains of the colon bacillus were grown in tryptone broth, with and without glucose supplementation, and in the defined glucose + glutamate medium. L-cysteine. $\mathrm{HCl}(0.05 \%, \mathrm{w} / \mathrm{v})$ was added to both media. In every case glucose enhanced cysteine desulphydrase activity, while being inhibitory to production of the enzyme if present in tryptone broth. Glucose enhancement of activity was greater in organisms recovered from tryptone broth (about 34- to $>100$-fold) than in those grown in glucose-fortified tryptone broth (about 3- to 14-fold). Specific activities ranged from 1.0 to $187 \mu \mathrm{g}$. $\mathbf{H}_{2} \mathrm{~S} / \mathrm{hr}$./mg. washed dry organisms. Organisms grown in glucose-supplemented tryptone broth were less active than organisms from plain tryptone broth, such difference being particularly striking when desulphydrase activity was measured in the presence of glucose.

\section{DISCUSSION}

Two routes of cysteine desulphydration are known: (i) the classical pyridoxal phosphate-dependent inducible cysteine desulphydrase yielding hydrogen sulphide and the unstable $\alpha$-aminoacrylic acid which hydrolyses to ammonia and pyruvic acid (Fromageot, 1951; Meister, 1957; Singer \& Kearney, 1955); (ii) de- or 
trans-amination reactions yielding an amino acid and an intermediate, $\beta$-mercaptopyruvic acid, which is decomposed by a desulphurase to pyruvic acid and sulphur (Hanson \& Mantel, 1953; Meister, Fraser \& Tice, 1954). Sulphur produced by the latter reaction is reduced to sulphide by thiosulphate, glutathione, cysteine, etc. (Hylin \& Wood, 1959; Sörbo, 1957). The $\beta$-mercaptopyruvic acid desulphurase is constitutive, has no requirement for vitamin $B_{6}$ and has no effect on $L$-cysteine. Hydrogen sulphide may also be produced from cysteine through elimination of ammonia with the formation of an intermediate that is neither $\alpha$-aminoacrylic or $\beta$-mercaptopyruvic acid (Suda, Saigo \& Ichihara, 1954).

While it is tempting to claim that a 'glucose effect' on yet another inducible enzyme has been demonstrated, the diversity of the aforementioned paths by which Escherichia coli can produce hydrogen sulphide from cysteine obscures interpretation of the results. The inhibitory effects of glucose in amino acid-containing media on the formation of 'cysteine desulphydrase' might be a result of repression of either the latter enzyme or of cysteine-pyruvic acid transaminase. In either case, formation of sulphide from cysteine would be impaired and the assay employed would not distinguish which mechanism was operative. Moreover, a dilemma arises in distinguishing between 'basal' cysteine desulphydration and that which is seemingly activated by glucose. Conceivably, cysteine degradation, with an intermediate product (pyruvic acid) common to one from glucose dissimilation, might be repressed by glucose when a good supply of amino acids encourage more vigorous synthesis of enzymes concerned with glucose degradation than was possible in an amino acid-limited menstruum.

The concept of active transport of amino acids (Britten \& McClure 1962; Christensen, 1955; Edelman, 1961; Gale \& Folkes, 1953; Kleinzeller \& Kotyk, 1961 ; Roberts et al. 1955) encourages speculation that an exogenously supplied energy source facilitates the assimilation of L-cysteine, thereby maximizing the activity of cysteine desulphydration. Kun, Bradin \& Dechary (1956) reported that the degradation of cysteine to sulphide by Endamoeba histolytica was completely dependent upon concurrent glycolysis while producing sulphide from cysteine. To date, a cysteine permease has not been reported, although glucose is strongly inhibitory to the induction of $\beta$-galactoside permease (Cohn $\&$ Horibata, 1959) and indifferent in the induction of tryptophan permease (Freundlich \& Lichstein, 1960). Since sonically disrupted cysteine-induced organisms were stimulated by glucose to produce sulphide from cysteine, glucose activation may operate at subcellular barriers, some of which are known to control enzymic function (Gross, 1959; Siekevitz, 1959). Delwiche (1951) noted that most of the cysteine desulphydrase activity resided in the particulate fraction of Escherichia coli.

Because the pathway by which hydrogen sulphide is produced from cysteine was obscure in this study, experiments in which glucose and $\alpha$-ketoglutarate were shown to affect the rates of appearance and relative amounts of ammonia and hydrogen sulphide from washed cysteine-induced organisms suggest that more than one mechanism was operative. Both glucose and $\alpha$-ketoglutarate might encourage transamination reactions with cysteine to result in the formation of $\beta$-mercaptopyruvate and alanine (transamination with pyruvate) or glutamic acid (transamination with $\alpha$-ketoglutarate). While glucose raised appreciably the molar ratios of sulphide to ammonia, alanine could not be detected in the reaction mix- 
tures. On the other hand, $\alpha$-ketoglutarate lowered the ratio of these products and slowed down their rate of appearance, suggesting the intervention of some mechanism other than transamination. Metaxas \& Delwiche (1955) reported $\alpha$-ketoglutarate to discourage sulphide formation from L-cysteine in alumina-ground Escherichia coli, an effect attributed to competition for a limited supply of pyridoxal phosphate. Glucose activation of the sulphide-producing system studied probably was a result of cysteine-pyruvate transaminase activity since it raised the ratio of sulphide to ammonia and, in some cases, apparently caused the accumulation of sulphur and polysulphide, evidence of $\beta$-mercaptopyruvic desulphurase activity (Hylin \& Wood, 1959). Further work is needed to unravel the apparent glucose activation and repression effects and to establish the nutritional role of amino nitrogen and glucose in cysteine catabolism.

This investigation was supported in part by grant E-353 from the National Institutes of Health, U.S. Public Health Service.

\section{REFERENCES}

Bethge, P. O. (1953). On the volumetric determination of hydrogen sulfide and soluble sulfides. Analyt. chim. Acta, 9, 129.

Britten, R. J. \& McClure, F. T. (1962). The amino acid pool in Escherichia coli. Bact. Rev. 26, 292.

Christensen, H. N. (1955). Mode of transport of amino acids into cells. In $A$ Symposium on Amino Acid Metabolism, p. 63. Ed. by W. D. McElroy \& H. B. Glass, Baltimore: The Johns Hopkins Press.

Cohn, M. \& Horibata, K. (1959). Physiology of the inhibition by glucose of the induced synthesis of the $\beta$-galactoside-enzyme system of Escherichia coli. J. Bact. 78, 624 .

Conway, E. J. (1950). Microdiffusion Analysis and Volumetric Error, 3rd ed., Chap. 10. London: Crosby, Lockwood and Son Ltd.

Davis, B. D. \& Mingroli, E. S. (1950). Mutants of Escherichia coli requiring methionine or vitamin $\mathrm{B}_{12}$. J. Bact. $60,17$.

Delwiche, E. A. (1951). Activators for the cysteine desulfhydrase system of an Escherichia coli mutant. J. Bact. 62, 717 .

Desnuelee, P. \& Fromageot, C. (1939). La décomposition anaérobie de la cystéine par Bacterium coli. I. Existence d'une cystéinase, ferment d'adaptation. Enzymologia, 6, 80.

Edelman, I. S. (1961). Transport through biological membranes. Annu. Rev. Physiol. 23, 37.

Freundich, M. \& Lichstein, H. C. (1960). Inhibitory effect of glucose on tryptophanase. J. Bact. 80, 633.

Fromageot, C. (1951). Desulfhydrases. In The Enzymes, I (part 2), 1237. Ed. by J. B. Sumner \& K. Myrbäck. New York: Academic Press, Inc.

Fromageot, C., Wookey, E. \& Chaix, P. (1940). Sur la dégradation anaérobie de la cystéine par la désulfurase du foie. Enzymologia, 9, 198.

Gale, E. F. \& Folkes, J. P. (1953). The assimilation of amino acids by bacteria. 14. Nucleic acid and protein synthesis in Staphylococcus aureus. Biochem. J. 53, 483.

Gross, S. R. (1959). Enzymatic autoinduction and the hypothesis of intracellular permeability barriers in Neurospora. Trans. N.Y. Acad. Science, Ser. II, $22,44$.

Hanson, J. \& MaNTEL, E. (1953). Untersuchungen über den intermediaren S-Stoffwechsel. IV. Über die im Substrat gelegenen Bedingungen der Desulfurierbarkeit durch Escherichia coli. Hoppe-Seyl. Z. 295. 141.

HyLIN, J. W. \& Wood, J. L. (1959). Enzymatic formation of polysulfides from mercaptopyruvate. J. biol. Chem. 234, 2141. 
Kallio, R. E. (1951). Function of pyridoxal phosphate in desulfhydrase systems of Proteus morganii. J. biol. Chem. 192, 371.

Kallio, R. E. \& Porter, J. R. (1950). The metabolism of cystine and cysteine by Proteus vulgaris and Proteus morganii. J. Bact. 60, 607.

Kleinzeller, A. \& Kotyk, A., editors (1961). Membrane Transport and Metabolism. New York: Academic Press, Inc.

Kun, E., Bradin, J. L. \& Dechary, J. M. (1956). Correlation between $\mathrm{CO}_{2}$ and $\mathrm{H}_{2} \mathrm{~S}$ production by Endamoeba histolytica. Biochim. biophys. Acta, 19, 153.

Magasanik, B. (1957). Nutrition of bacteria and fungi. Annu. Rev. Microbiol. 11, 221.

Magasanik, B. (1962). Catabolite repression. In Cellular Regulatory Mechanisms. Cold Spr. Harb. Symp. quant. Biol. $26,249$.

Magasanik, B., Magasanik, A. K. \& Neidhardt, F. C. (1959). Regulation of growth and composition of the bacterial cell. In CIBA Foundation Symposium, Regulation of Cell Metabolism, p. 334. Ed. by G. E. W. Wolstenholme \& C. M. O'Connor. London: J. and A. Churchill Ltd.

Meister, A. (1957). Biochemistry of the Amino Acids, p. 316. New York: Academic Press, Inc.

Meister, A., Fraser, P. E. \& Tice, S. V. (1954). Enzymatic desulfuration of $\beta$-mercaptopyruvate to pyruvate. J. biol. Chem. 206, 561 .

Metaxas, M. A. \& Delwiche, E. A. (1955). The L-cysteine desulfhydrase of Escherichia coli. J. Bact. 70, 735.

OLITZKI, A. L. (1954). Hydrogen sulphide production by non-multiplying organisms and its inhibition by antibiotics. J. gen. Microbiol. 11, 160.

PARDEE, A. B. (1961). Response of enzyme synthesis and activity to environment. In Microbial Reaction to Environment Symp. Soc. gen. Microbiol. 11, 19.

Pardee, A. \& Prestidge, L. S. (1961). The initial kinetics of enzyme induction. Biochim. biophys. Acta, 49, 77.

Roberts, R. B., Abelson, P. H., Cowie, D. B., Bolton, E. I. \& Britten, R. J. (1955). Studies in Biosynthesis in Escherichia coli. Washington, D.C.: Carnegie Inst.

Siekevitz, P. (1959). On the meaning of intracellular structure for metabolic regulation. In CIBA Foundation Symposium, Regulation of Cell Metabolism, p. 17. Ed. by G. E. W. Wolstenholme \& C. M. O'Connor. London: J. \& A. Churchill Ltd.

Singer, T. P. \& Kearney, E. B. (1955). Enzymatic pathways in the degradation of sulfur-containing amino acids. In A Symposium on Amino Acid Metabolism, p. 558. Ed. by W. D. McElroy \& H. B. Glass. Baltimore: The Johns Hopkins Press.

SörBo, B. (1957). Enzymic transfer of sulfur from mercaptopyruvate to sulfite or sulfinates. Biochim. biophys. Acta, 24, 324.

Suda, M., Saigo, T. \& Ichihara, A. (1954). The action of L-cysteine desulfhydrase. I. Lcysteine desulfhydrase isolated from bacteria. Med. J. Osaka Univ. 5, 127. (Chem. Abstr. 48, 11508ab).

TAMIYA, A. (1954). Studies on aerobic decomposition of cysteine by Escherichia coli. I. J. Biochem. (Tokyo), 41, 199. 